\title{
Cain and Vulnerability: The Reception of Cain in Genesis Rabbah 22 and Targum Onkelos, Targum Neofiti and Targum Pseudo-Jonathan
}

\author{
GERRIE F. SNYMAN (UNISA) ${ }^{1}$
}

\begin{abstract}
This essay enquires into the reception of the story of Cain and Abel (Gen 4) in late ancient Judaism (Genesis Rabbah, Targum Onkelos, Targum Neofiti, and Targum Pseudo-Jonathan) with regard to the way Cain is portrayed differently from how he is depicted in the Hebrew text. The perspective from which his portrayal in the Jewish literature of late antiquity will be viewed is that of vulnerability or fragility, asking the question whether the reception of Cain in Jewish antiquity allow for such vulnerability in the interpretation of the story, or does he remain a villainous character who refused to be redeemed. The question of the redemption of Cain is formulated within a hermeneutic of vulnerability as a framework to deal with the perpetration of apartheid. The following aspects of the story are discussed: the birth of Cain, his occupation, the sacrifice, Cain's reaction to the sacrifice, the deity's questioning of Cain, the conversation in the field, the murder, the blood of Abel, Cain's curse, his response, and his punishment. The study concludes that although the reception portrays Cain as a villain par excellence, there are aspects in the representations that provide glimpses of redemption for Cain, implying a particular vulnerability.
\end{abstract}

KEYWORDS: Cain, Abel, hermeneutic of vulnerability, villain, Targums, Genesis Rabbah, Abel's blood, Cain's punishment, villain.

* Article submitted: 14/09/2016; accepted: 18/10/2016. To cite: Gerrie F. Snyman, "Cain and Vulnerability: The Reception of Cain in Genesis Rabbah 22 and Targum Onkelos, Targum Neofiti and Targum Pseudo-Jonathan," OTE 29 (3) 2016: 601-632. Doi: http://dx.doi.org/10.17159/2312-3621/2016/v29n3a14

1 This article is an edited version of a paper delivered at the $22^{\text {nd }}$ meeting of the International Organisation for the Study of the Old Testament. This work is based on research supported in part by the National Research Foundation of South Africa (Grant specific unique reference number [UID] 85867). I want to express my appreci-ation for Prof. Thomas Römer of the Milieux Biblique, Collège de France, Paris, for providing me with library access and support to do this research and Prof. Knut Holter of Vid Specialized University in Stavanger for providing a writing environment to write this paper. 
602 Snyman, “Cain and Vulnerability,” OTE 29/3 (2016): 601-632

\section{A INTRODUCTION}

This essay is part of an ongoing research into the notion of vulnerability and Cain as perpetrator. ${ }^{2}$ At issue in the research is the discourse on racism, the notion of perpetratorhood and the conduct of the perpetrator (racist) when confronted with wrongdoing. In the current socio-political South African context, this study finds it resources in racialised discourse with the general aim of laying bare thought structures that enable racialised discourse. ${ }^{3}$

But revealing these structures are not sufficient because no one wants to be exposed as a perpetrator. ${ }^{4}$ No one wants to be branded a racist because it is bad. Needless to say, when challenged, or insinuating complicity in racism, a specific fragility is exposed. Fragility is that condition in which the minimum amount of stress (in this case, racial stress) becomes intolerable and triggers a range of self-justifying or self-protecting moves, such as anger, fear, or guilt, as

2 See Gerrie F. Snyman, “A Hermeneutic of Vulnerability: Edom in Malachi 1:2-5,” (paper presented at the annual meeting of the Society of Biblical Literature, Atlanta, USA, 20 November 2015); Gerrie F. Snyman, “A Hermeneutic of Vulnerability: Redeeming Cain?” Stellenbosch Theological Journal 1 (2015): 633-665, doi: http://dx.doi.org/10.17570/stj.2015.v1n2.a30. Gerrie F. Snyman, "Obadiah and a Hermeneutic of Vulnerability,” in Obadiah, ed. Bob Becking, Readings (Sheffield: Sheffield Phoenix, 2016), 45-63. Gerrie F. Snyman "Responding to the Decolonial Turn: Epistemic Vulnerability,” Missionalia 43 (2015): 266-91, http://dx.doi.org/10. 7832/43-3-77.

An estate agent in in KwaZulu-Natal South Coast called revelers on the beach on New Year's Eve and New Year's Day "monkeys.” These revelers were black and Sparrow is white. Cf. Jeff Wicks, "Twitter Erupts after KZN Estate Agent Calls Black People 'Monkeys,"” Mail \& Guardian, 4 January 2016, http://mg.co.za/article/201601-04-twitter-erupts-after-kzn-estate-agent-calls-black-people-monkeys. In June, a pastor in Sandton claimed white innocence in the face of racism, such as that white people never took anything from black people and that they were sent to black people by God. Cf. Ahmed Areff, "Listen: Whites Took Nothing from No One - Pastor Andre Olivier,” News24.com, 28 June 2016, http://www.news24.com/SouthAfrica /News/listen-whites-took-nothing-from-no-one-pastor-andre-olivier-20160628. The Ahmed Katrada Foundation issued a statement by Prof. Klippies Kritzinger in which he stated that Olivier needs to bid farewell to innocence, ignorance and arrogance. Cf. Klippies (J. N. J.) Kritzinger, "Response to Pastor Andre Olivier of Rivers Church, Sandton,” Ahmed Kathrada Foundation, 1 July 2016, http://www.kathrada foundation.org/tags/klippies-kritzinger.

4 Robin Diangelo, What Does It Mean to Be White? Developing White Racial Literacy, Counterpoints 398 (New York: Peter Lang, 2012), 7 argues that society teaches its members that racism is committed by a few bad people. In the process, a binary is constructed of racist and not racist, creating a binary of perpetrators and innocents. Thus, "if you are a racist, you are ignorant, bigoted, prejudiced, mean-spirited, ... If you are not a racist, you are nice, well-intentioned, open-minded, progressive, and 'don’t have a prejudiced bone in your body.'” 
well as arguing, silence, or simply physical withdrawal in order to restore (white racial) stability. ${ }^{5}$ Because of the stigma attached to racism, any exposure of racialised discourse needs to present the perpetrator a moment in which he or she can move from fragility to vulnerability-a moment of redemption in which the perpetrator's fragility becomes an acknowledged vulnerability from which change can take place.

It is this vulnerability that is the object of study in the reception of the figure of Cain: ${ }^{6}$ does the reception of Cain in Jewish antiquity allow for such vulnerability in the interpretation of the story in, for example, Genesis Rabbah or the Targum Onqelos, Targum Neofiti or Targum Pseudo-Jonathan? Or, does Cain remain the enemy, the intolerable Other, which we need, in the words of the late Umberto Eco,

not only to define our identity but also to provide us with an obstacle against which to measure our system of values and, in seeking to overcome it, to demonstrate our own worth[.] So when there is no enemy, we have to invent one. ${ }^{7}$

But what happens when you have become the enemy, the perpetrator, as is now the case with regard to whiteness and racism? Ignorance of vulnerability with regard to racism is ethically and politically dangerous, as the recent incidents with regard to racism have shown. ${ }^{8}$ Vulnerability is seen as a negative condition and invulnerability more desirable:

5 Diangelo, What Does It Mean to Be White?, 183.

6 Katharina von Kellenbach, The Mark of Cain: Guilt and Denial in the Post-War Lives of Nazi Perpetrators (Oxford: Oxford University Press, 2013), 27-8 assumes such vulnerability in her reading of Cain and Nazi perpetrators: "While the biblical Cain could be banished to the land of Nod, we have run out of remote places where those who carry grave guilt can be deported. Increasingly, our world has grown together so closely that we will not be able to give up and write off anyone in the global family. We cannot execute or imprison the thousands who require the medicine of retribution. Hence, we must develop different strategies that heal past hurts and that detoxify the poisons of hate and of guilt. That is why the mark of Cain, the path of radical transparency, commends itself. When the first generation fails to accept the challenge, its descendants inherit the task. But there is an inexplicable imperative toward at-one-ment, or a coming back together, that can be trusted.”

7 Umberto Eco, Inventing the Enemy and Other Occasional Writings, trans. Richard Dixon (London: Harvill Secker, 2012), 2. In his essay, Eco shows how various authors of antiquity constructed and demonised the enemy: they are the different and the strange, the foreigner, the Jew, the witch, the ugly, the Negro, all who lack beauty, stink, appear monstrous, cannibalistic, lower class, the criminal, the prostitute.

8 Gloria Wekker, White Innocence: Paradoxes of Colonialism and Race (Durham, N.C.: Duke University Press, 2016), 18, makes the point that "innocence speaks not 
Invulnerability, accordingly, is a stance that enables us to ignore those aspects of existence that are inconvenient, disadvantageous, or uncomfortable for us, such as vulnerability's persistence. As invulnerable, we cannot be affected by what may unsettle us. ${ }^{9}$

This is perhaps the reason why no one voluntarily picks up the role of the perpetrator, because one then becomes part of the construction of the enemy and thus vulnerable. However, vulnerability is a basic human condition and constitutes openness "to being affected and affecting in both positive and negative ways." "10 Gilson defines it as follows:

Being vulnerable makes it possible for us to suffer, to fall prey to violence and be harmed, but also to fall in love, to learn, to take pleasure and find comfort in the presence of others, and to experience the simultaneity of these feelings. Vulnerability is not just a condition that limits us but one that can enable us. As potential, vulnerability is a condition of openness, openness to being affected and affecting in turn. ${ }^{11}$

In my quest to open up apartheid perpetrator discourse towards the notion of vulnerability (in order to facilitate a wider discourse on reconciliation), the figure of Cain has become central. ${ }^{12}$ Discourse in the biblical story of Cain is in itself problematical. The reader never sees a discussion with Abel and the deity's speech is more a monologue than a dialogue. André Wénin argues that the lack of discourse is central to Cain's problem; amidst all the questions the deity poses, there is an invitation to put one's fears in words: to master a desire is to tell a story. ${ }^{13}$ When the deity exhorts Cain to master his desire, he also suggests to Cain to put his fears in words. But instead, Cain became fragile: he is aggressive and kills.

In as much as the interpretive tradition keeps on portraying Cain in negative terms, and attribute to him various crimes and negative dispositions, ${ }^{14} \mathrm{a}$ perpetrator discourse in which the vulnerability of the perpetrator is pursued

only in soft, harmless, childlike qualities, ... it is strongly connected to privilege, entitlement, and violence that are deeply avowed."

9 Erinn Gilson, "Vulnerability, Ignorance, and Oppression,” Hypatia 26 (2011): 313, doi: 10.1111/j.1527-2001.2010.01158.x.

10 Gilson, "Vulnerability," 310.

11 Gilson, "Vulnerability," 310.

12 Snyman, "Hermeneutic of Vulnerability: Redeeming” 633-665.

13 André Wénin, “Adam et Eve: La Jalousie de Caïn, "semence» du Serpent : Un Aspect du Récit mythique de Genèse 1-4,” RevScRel 73 (1999): 13.

14 Cain did not become only a murderer he also turned into an oppressor of the poor and a teacher of evil practices. See John Byron, Cain and Abel in Text and Tradition: Jewish and Christian Interpretations of the First Sibling Rivalry, TBNJCT (Leiden: Brill, 2011), 211. 
remains impossible. There are various examples within the early Christian interpretation in which Cain remains the ultimate villain. Angela Kim argues

Ancient interpreters introduce elements to resolve theological problems that are implied by YHWH's rejection of Cain's sacrifice. Ancient exegetes magnify elements of sibling rivalry and envy in order to provide the necessary situation of conflict between the brothers. By so doing, the ancients deflect attention away from YHWH and the problem of God's capriciousness. Through translation techniques, characterizations and the incorporation of legendary accretions, the story is reshaped by the magnification of envy during the post-biblical period and emerges anew as a tale of envious rivalry between good and evil. ${ }^{15}$

The question in this essay is what happens to Cain in the Jewish interpretation. The MT in Gen 4, when compared to the Jewish interpretive tradition as manifested in the various Targums and the Midrash in Genesis Rabbah, indicates gaps that are filled by the ancient readings so that the story is expanded and Cain's character portrayal is augmented in various ways that do not only turn him into a villain par excellence. In the Masoretic presentation of the story he seems to move from fragility (Am I my brother's keeper?) to vulnerability (My punishment is too great to bear). Does the reception of the story in the three mentioned Targums as well as Genesis Rabbah allow for a similar vulnerability or is he depicted as the murderer par excellence for whom no redemption is possible?

\section{B FIELD OF STUDY AND ITS LIMITATIONS}

In terms of what is already present in the field it is difficult to say something new about the Cain and Abel story. John Byron's book, Cain and Abel in Text and Tradition provides an excellent primer to study the reception of the story in the Jewish and Christian traditions. ${ }^{16}$ Byron's book is a valuable resource in this regard:

It is a wide-ranging study that analyses how the Cain and Abel story was expanded and reinterpreted; and particular attention is devoted to considering themes developed in extra-biblical literature which made the story attractive to these authors. ${ }^{17}$

He traces the interpretive history of the story of Cain and Abel and relates them as they appear relevant in his analysis of each verse or group of verses. Subsequently the various interpretive histories are linked to specific

15 Angela Y. Kim, "Cain and Abel in the Light of Envy: A Study in the History of the Interpretation of Envy in Genesis 4.1-16,” JSP 12 (2001): 84.

16 John Byron, Cain and Abel.

17 Byron, Cain and Abel, 6. 
verses and the reader does not get an impression what a single tradition does with the story. Byron's goal is to appreciate the traditions within a broader interpretive context whereas the current essay wants to draw attention to a specific reception of the story in the tradition, for example, the Jewish interpretive tradition in Genesis Rabbah and the Targums.

Ruth Mellinkoff's book The Mark of Cain does something similar, but her focus is on the reception of the mark of Cain in the history of interpretation. ${ }^{18}$ Robert Gregg's monumental volume on shared stories in the HB, the Christian Bible and the Qur'an shows how Jews, Christians and Muslims heard, read, and utilised differently the stories these three religions share. One of them he discusses is Cain and Abel in terms of rabbinic reception where Abel's righteousness is contrasted with the evil of Cain; the Early Christian reading of the story in terms of vice and virtue, Cain's criminality and Abel's victimhood; and lastly, the Qur'anic presentation of the story with a tradition not found in the other two religions, in which Cain's (called Qabil) character is reassessed. ${ }^{19}$ Whereas these three books draw on various traditions' reception of the Cain and Abel story, Johanna Erzberger's study (Kain, Abel und Israel: die Rezeption von Gen 4, 1-16 in rabbinischen Midraschim) focuses on the interpretation of the story in rabbinical Midrash, inter alia, the Genesis Rabbah ${ }^{20}$ Her study quickly revealed the shortcomings of my own interpretation in terms of reading the Aramaic, something I could not do well. My interest in the Targums and Genesis Rabbah is not linguistic or grammatological. I am not a Judaica scholar. My interest at this stage is informational: how does the Midrash interpret the story of Cain and Abel in terms of the characterisation of Cain and vulnerability? The same is true for the Aramaic text in the Targums. In all four cases the translations proved to be helpful, but my goal is not to ask why they arrived at their respective readings. A fifth book that shaped my comprehension of these traditions were Gudrun Lier's monograph in which she provides background to the origin, shape and production of Targum Onkelos, Neofiti and Pseudo-Jonathan. ${ }^{21}$ Her focus differs from this essay's (hers is on Gen 1:26-7) but the discussion of the Targums in the second chapter enabled me to under-

18 Ruth Mellinkoff, The Mark of Cain (Berkeley: University of California Press), 1981.

19 Robert C. Gregg, “Cain and Abel/Qabil and Habil,” in Shared Stories, Rival Tellings: Early Encounters of Jews, Christians, and Muslims, ed. Robert C. Gregg, (Oxford: Oxford University Press, 2015), 1-113.

20 Johanna Erzberger, Kain, Abel Und Israel: Die Rezeption von Gen 4, 1-16 in Rabbinischen Midraschim, BWANT 12 (Stuttgart: Kohlhammer, 2011).

21 Gudrun E. Lier, A Redaction History of the Pentateuch Targums: Genesis 1:26-27 in the Exegetical Context of Formative Judaism, GorBS 53 (Picastaway: Gorghias Press, 2014). 
stand the role of the Targums much better than the information provided in Würthwein $^{22}$ and Deist. ${ }^{23}$

\section{EXCURSUS: SOME NOTES ON MIDRASH, TARGUMS AND GENESIS RABBAH}

To understand the Targums and Genesis Rabbah, one needs to understand the nature of Midrash. ${ }^{24}$

[T]he term "midrash" designates an exegesis which, going more deeply than the mere literal sense, attempts to penetrate into the spirit of the Scriptures, to examine the text from all sides, and thereby to derive interpretations which are not immediately obvious. $^{25}$

Midrash constitutes a commentary of a biblical book, either on the entire book or parts of it, probably originating in the Talmudic period or earlier, constituting "literary representatives of a much older, oral process which dates back long before the beginning of the Christian era." 26 This format was continued into the Talmudic period, with Genesis Rabbah "the largest, most comprehensive midrashic commentary to any individual book of the Bible.”27

Genesis Rabbah is not a scholarly text and is intended for a popular audience in the synagogue. It is an exegetical Midrash on the Book of Genesis and constitutes a verse-by-verse and sometimes a word-for-word commentary on Genesis and differs from other homiletic literature ${ }^{28}$ on the biblical texts which do not provide comments on individual sections such as verses or

22 Ernst Würthwein, The Text of the Old Testament: An Introduction to the Biblia Hebraica, trans. Erroll F. Rhodes (Grand Rapids: Eerdmans, 1995).

${ }^{23}$ Ferdinand Deist, Witnesses to the Old Testament, vol. 5 of The Literature of the Old Testament (Pretoria: NG Kerkboekhandel, 1988).

24 Erzberger, Kain, 13 and 15.

25 Joseph Jacobs and S. Theodore Horovits, "Midrash,” JE 8:548-550. In the period of the Amoraim Midrash became contradistinctive from the term "peshat" which came to designate at that stage "natural and simple sense of Scripture" over-against Midrash which, by then, came to be regarded as "forced and artificial." (See Wilhelm Bacher and Jacob Z. Lauterbach, "Peshat,” JE 9:652-53.

26 Irving Jacobs, The Midrashic Process: Tradition and Interpretation in Rabbinic Judaism (Cambridge: Cambridge University Press, 1995), 16.

27 Jacobs, Midrashic Process, 16.

28 Joseph Heinemann, "The Proem in Aggadic Midrashim: A Form-Critical Study,” in Studies in Aggadah and Folk-Literature, ScrHier 22, ed. Joseph Heinemann (Jerusalem: Magnes Press, Hebrew University, 1971), 101. 
words. $^{29}$ It uses Palestinian Aramaic in which popular stories and anecdotes were transmitted: “This suggests once again that the popular sermons and expositions of the ancient synagogues, in whatever form they were recorded, were a major source for the material in Genesis Rabbah." 30

Bernard Grosfeld, the editor of the Targum Onqelos to Genesis, suggests then that there is a close affinity between the Genesis Rabbah originating in Palestine and Targum Onqelos (originating in Babylon) which he relates to a proto text (in Palestine) of Targum Onqelos which they both shared. ${ }^{31}$ Martin McNamara is of the opinion that Targum Neofiti is an example of the Palestinian Targums that are said to have had a function in the synagogue. ${ }^{32}$ In contrast, Michael Maher regards Targum Pseudo-Jonathan to be compiled within an academic setting, or at least, a non-synagogue environment. ${ }^{33}$

Gudrun Lier provides a view on the intricate and complex nature of the origins of the Targums, ${ }^{34}$ but she suggests an academic or learned background for all three, although each had a different aim. ${ }^{35}$ According to Lier, the impact of the Destruction was of such a nature that priests and rabbis became "an integral group of scholars”,36 after the Destruction, resulting in the development and standardization of the liturgy in the Synagogue. ${ }^{37}$ But it did not result in a vernacular translation: "Rather, the fixed authorized rendition was used to extract meaning from the sacred text in the context of the academy and to set that exegesis off against the Hebrew Text of Scripture." 38 The result was the Targum Onqelos and Targum Neofiti. Lier also argues that there are Targums that were compiled for contexts different from the liturgical one of the Syna-

29 Harry Freedman, "Introduction," in Midrash Rabbah Genesis: Translated into English with Notes, Glossary and Indices with Foreword by Rabbi. Dr. I. Epstein vol. 1, ed. Harry Freedman and Maurice Simon (London: Soncino Press, 1961), 27-29.

30 Jacobs, Midrashic Process, 17. The material is based on sermons and expositions once performed in front of or delivered to live audiences.

31 Tg. Onq. Gen. 18.

32 Tg. Neof. Gen. 2.

33 Michael Maher, Targum Pseudo-Jonathan: Genesis. Translated, with Introduction and Notes, vol. 1b (The Aramaic Bible. Edinburgh: T \& T Clark, 1992).

34 Lier, Redaction History, 17-80. Lier's study contributes immensely to the South African understanding of the Targums as reflected in the standard textbook, Deist, Witnesses, 117-137.

35 Lier, Redaction History, 28-9; 71-3.

36 Lier, Redaction History, 30.

37 Lier, Redaction History, 31-2. With the temple destroyed new ways were sought to unify the traumatised people of the Jewish nation, such as establishing new centres for learning and introducing new regulations that filled the gap left by the Destruction.

38 Lier, Redaction History, 69. 
Snyman, “Cain and Vulnerability,” OTE 29/3 (2016): 601-632

gogue, such as Pseudo-Jonathan. The latter is composed in three Aramaic dialects and exhibit different layers of redaction. ${ }^{39}$

The comparison between the Targums, with one another as well as with Genesis Rabbah, does not constitute a way to see which text influenced which text. ${ }^{40} \mathrm{I}$ am more inclined to follow Pierre Grelot with regard to the Targums when he asks:

Peut-on parler vraiment de fixation? Plutôt qu'à un texte fixe ne varietur, ne doit-on pas songer à une tradition encore vivante, articulée sur des thèmes précis exprimés dans un vocabulaire toujours repris, mais encore souple et susceptible de développements ultérieurs? La seconde manière de voir est évidemment la plus vraisemblable. $^{41}$

There is no simple progression from one Targum to another. Each is distinctive in its own way, yet simultaneously corresponding to the other. Each time a theological debate is augmented by an argument about a theodicy. ${ }^{42}$ Avigdor Shinan warns that differentiating

between the two groups of literature, synagogue and Bet Midrash, and between the internal components of both, does not, of course, stand upon a razor's edge, since they were created by the same world of religious thought and orientation. ${ }^{43}$

39 Lier, Redaction History, 205.

40 Avigdor Shinan, "The Aggadah of the Palestinian Targums of the Pentateuch and Rabbinic Aggadah: Some Methodological Considerations," in The Aramaic Bible: Targums in Their Historical Context ed. Derek R. G. Beattie and Martin J. McNamara, JSOTSup 166 (Sheffield: Sheffield Academic Press, 1994), 207 suggests there are two ways to interpret similarities and differences: either to assume a direct dependence between the Targums and Midrash (in both directions) or to assume indirect dependence with the utilisation of a common source. In terms of the direction of dependence, Shinan, "Aggadah," 208, is of the opinion there is not sufficient tools to determine which text is dependent of which text. Determining the direction of dependence is, however, not the aim of my paper.

41 Pierre Grelot, "Les Targums du Pentateuque: Étude Comparative d'après Genèse IV, 3-16,” Sem 9 (1959): 86.

42 Bruce Chilton, "A Comparative Study of Synoptic Development: The Dispute between Cain and Abel in the Palestinian Targums and the Beelzebul Controversy in the Gospels,” JBL 101 (1982): 559. Vermes and Grelot have affirmed the mutuality between and the distinctiveness of each Targumic text of Gen 4. See Geza Vermes, “The Targumic Versions of Genesis 4:3-16," in Post-Biblical Jewish Studies, SJLA 8 (Leiden: Brill, 1975), 92-126.

43 Shinan, “Aggadah,” 203. 


\section{DEPICTION OF CAIN IN THE TARGUMS AND GENESIS RABBA}

\section{Birth of Cain}

The story of Cain and Abel in the MT (Gen 4) starts with a scene of conception, followed by the subsequent birth of Cain. At stake is the word ידע with Adam either having sex with his wife or knowing something else about her. ${ }^{44}$ $\mathrm{Tg}$. Onq. and Tg. Neof. understood the text to mean having sex, but Tg. Ps.-J. interpreted the story in terms of knowledge production: Adam knew about the unfaithfulness of his wife, as she had intercourse with Samael, an angel of the Lord. In Jewish tradition he is the prince of demons and responsible for the temptation of Eve in the Garden of Eden. He subsequently lures her also sexually, with Cain as a result. Thus, from Cain it is not said that he is in the likeness of his father, Adam, whereas it is explicitly noted in the birth notice of Seth in Gen 5:3. The absence here of the formula present in Gen 5:3 led interpreters to assume that the father of Cain was someone else. Moreover, Eve does not refer to Cain as a son, but as a man-a full grown male: Cain seems to be powerful already (he is a man) and possess a certain quality — his origins lie with divine beings interpreted as fallen angels. ${ }^{45}$ The snake, as symbol of Samael, then becomes the likely suspect. ${ }^{46}$ Hence $T g$. Ps.-J.'s link of Cain to Samael.

The odds appear to be stacked against Cain in a part of the tradition where he does not enjoy any benefit of doubt. With Eve bringing evil into the world, $T g$. Ps.- $J$ does not have any reference to her exclamation of joy at the birth of her first-born, over-against $T g$. Onq. and Tg. Neof. in which the exclamation is repeated, yet with a different translation in order to avoid the muchfeared anthropomorphisms in representing the deity. The את יהוה is understood

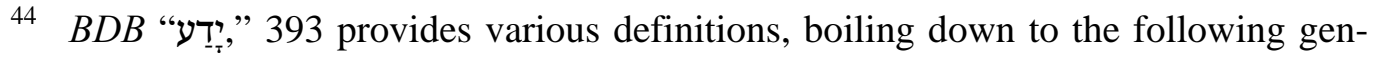
eral meanings: to know good from evil, to know a person, to know a person carnally (sexually), to be knowledgeable (skilful), to be wise, and to know God.

45 Byron, Cain and Abel, 18: "Cain was half-human and half-angelic having been fathered by the devil or some other fallen angel."

46 See Louis Ginzberg, Bible Times and Characters from the Creation to Jacob, vol. 1 of The Legends of the Jews, transl. Henrietta Szold (Philadelphia: The Jewish Publication Society of America, 1954), http://philologos.org/_eb-lotj/vol1/three.htm\#1: "Wickedness came into the world with the first being born of a woman, Cain, the oldest son of Adam. When God bestowed Paradise upon the first pair of mankind, He warned them particularly against carnal intercourse with each other. But after the fall of Eve, Satan, in the guise of the serpent, approached her, and the fruit of their union was Cain, the ancestor of all the impious generations that were rebellious toward God, and rose up against him. Cain's descent from Satan, who is the angel Samael, was revealed in his seraphic appearance. At his birth, the exclamation was wrung from Eve, 'I have gotten a man through an angel of the Lord.'” 
as "from before the Lord" and not "with the help of the Lord" as in the translations of the MT: "I have acquired a man with the help of the Lord." The two Targums read: "I have acquired a man from before the Lord." The exclamation is nonetheless understood as a woman proclaiming her bond with the husband, he is now in her possession-a security for her social and familial status. ${ }^{47}$ But it also means that God is involved in the conception of human beings, even in the case of Cain.

Gen. Rab. 22.2 understands this construction as teaching: from now onwards there will no longer be creation from clay or soil, but propagation through men and women copulating. Erzberger, who sees teaching and learning a central concept in Gen. Rab. 22 thus sees Adam as a teacher. ${ }^{48}$ Adam is a teacher and Cain eventually also becomes a teacher. But his teaching is one of misery and evil so that others may learn from it.

Gen Rab. 22.2 accepts that Eve conceived (with Adam as the father), but to this tradition, not only two children were born, Cain and Abel, but three more. It is a joyous occasion, as Rabbi Eleazar ben Azarja states that three miracles happened on this day: Adam and Eve were created, they had sex and they produced offspring. Rabbi Jehoshua ben Karcha argues that two went onto the bed and seven came out: Cain and his twin sister and Abel and two twin sisters. The issue of twins is read into the report on the birth of Abel: because the text does not suggest another conception as is the case with Cain, the birth of Abel is regarded as a continuance ${ }^{49}$ of the act of giving birth after Cain, making them twins and not brothers where the one is older than the other and having a right to certain privileges as was the case between Jacob and Esau. Nonetheless, the proximity of age introduces sibling rivalry which becomes a rivalry over a woman in the form of the twin sister in the hypothesised dialogue between Cain and Abel. ${ }^{50}$

Tg. Ps. $-J$. follows the tradition that attaches twin sisters to Cain (and Abel). It expands on the MT version by adding that Abel's father was Adam and that with him was born a twin sister: "Then, from Adam her husband she bore his twin sister and Abel. Abel was a keeper of the sheep, and Cain was $a$ man tilling the earth.” Tg. Ps.-J. makes Cain and Abel not full brothers though. ${ }^{51}$ In Gen. Rab. 22.3 they are twin brothers, with twin sisters specifically

47 Erzberger, Kain, 69.

48 Erzberger, Kain, 94.

49 Byron, Cain and Abel, 23 argues that this understanding is, for example in Pirqe Rabbi Eliezer, the result of reading the MT differently. In the MT there is a double verbal form translated as "she bore again" which Pirqe $R$. El. read as an imperfect with an infinitive "she continued to bear."

50 Kim, "Cain and Abel," 81 and 83.

51 Byron, Cain and Abel, 25 bases his argument on the presence of a double "This double occurrence of the direct object marker indicated a double birth to the 
linked to each of them. The addition of the twin sisters provides an implied explanation of where Cain will find his future wife. It also gives a reason for the conflict between him and Abel.

\section{Cain's Occupation}

On the issue of the work of Abel and Cain-Abel as keeper of the flocks and Cain as tiller of the soil-Gen. Rab. 22.3 mentions three instances where tilling the soil failed to produce any joy despite a particular passion for agriculture: Cain is a tiller of the soil (Gen 4:2), Noah is a man of the soil (Gen 9:20) and Uzziah in 2 Chr 26:10 is described as a lover of the soil. What connects them is the reference to אדמה. ${ }^{52}$ Eventually Cain became a murderer, Noah a drunkard and Uzziah a leper. All three are ultimately excluded from society. Erzberger is of the opinion that Gen. Rab. does not pronounce here a value judgment on agriculture. ${ }^{53}$ There is, nevertheless, a negative link drawn between tilling the soil and the outcomes in the lives of these three men. Tilling the soil does not bode well for the tiller. Another rabbinical text, Pirqe R. El. 21, relates passion to the two boys' occupation: Cain was a man who loved the ground in order to sow seed and Abel loved to tend sheep. Moreover, both is said to have given the other of his produce as food. There was equilibrium in society.

Nothing is really said about Abel's profession. What the rabbis did pick up was Abel's supposed age at the time of the offering: 50 days. The suggestion is that he was younger than Cain-was he thus more vulnerable? Or did his youth make him stronger? Later on Cain is said to have risen up against Abel and struck him down only by deception. ${ }^{54}$ Of larger concern was the kind of sacrifice Cain and Abel brought: a gift or an offering, and more specifically, a peace offering.

\section{$3 \quad$ Sacrifice}

Abel's sacrifice, the sheep and its fat, is treated in detail and seen as an important marker for sacrifice within ancient Israel's history of sacrifice. ${ }^{55}$ In

translator and that Abel, therefore, had a twin who was his sister.” Byron then ascribes the Genesis Rabbah reading to the presence of this double את.

52 Erzberger, Kain, 70.

53 Erzberger, Kain, 70. Josephus’ (Ant. 121.52-5) negative connotation towards tilling of the soil as products "forced from nature by the ingenuity of grasping man" is linked by Jack P. Lewis to Gen Rabbah 22.3 without any argument. See Jack P. Lewis, "The Offering of Abel (Gen 4:4): A History of Interpretation," JETS 37 (1994): 485.

54 Lewis, “Offering of Abel," 491.

55 Abel's sacrifice is related to the issue of peace offerings or burnt offerings, the former more regular and the latter on specific days or at specific occasions. Erzberger, Kain, 75 says that "[d]as Beispiel des Opfers Abels dient der Konstruktion eines zeitlichen Koordinatensystems, dessen Nullpunkt die Gabe der Tora ist. Während die 
Gen. Rab. 22.5 the nature and value of the sacrifice is important, since Abel's offering is accepted and Cain's rejected. No reason is given, but the rabbis looked for a reason in investigating how the sacrifices were defined in the text. Cain's sacrifice is summarily dismissed as being of inferior quality in not bringing the first figs, which is deemed a delicacy at the time, according to Isa 28:4 and Jer 24:2. ${ }^{56}$ Cain did not follow the regulations concerning sacrifice. His timing was not correct and the contents of the offering flawed. Byron thinks the Targums' explicit reference to the date (14 Nissan or Passover) is an effort to implicate Cain:

It is possible that, in the light of the sacrificial context and Abel's offering of the firstlings of his flock, the problem was viewed not to be with Cain's offering, but the time in which he offered that type of offering. $^{57}$

In other words, Cain too should have brought a lamb as his brother, and NOT from his first fruits, namely, flax that flowers in early spring. ${ }^{58} \mathrm{He}$ is in effect accused of poor sacrificial practices. But Vermes draws the attention to the function of 14 Nissan within ancient Judaism: great events are related to Nissan: creation, the sacrifice of Isaac and the first Passover. Here the first sacrifice and murder of an innocent man also takes place in Nissan. ${ }^{59}$

The rabbis' discussion of and focus on Abel's sacrifice in Gen. Rab. 22.5 is in stark contrast to the somewhat cursory nature of the discussion on Cain's offering. He was simply the son of Satan and acted according to his being. Abel's sacrifice has a theological meaning and effect attached to it. Cain's sacrifice is dealt with very briefly and decisively. Abel's sacrifice is redeemed and related to other sacrifices and the presentation of the Law at Sinai. Cain's offering is regarded as that of a bad tenant who kept the best fruits for himself. $T g$. Ps. $-J$. is the only one of the Targums suggesting what the kind of first fruits it was that Cain brought, namely flax seed whereas Gen. Rab. looked for figs. Abel's offering is defined as the first born of his sheep and

jungen Männer Israels und die Kinder Noahs ein inner- und außerhalb Israels repräsentieren, steht das Opfer Abels am Anfang einer Dynamik, die in der Gabe der Tora ihren Höhepunkt findet.”

56 Isaiah refers to figs that is ripe before the arrival of summer with whomever spotting them picking them immediately and swallow them while not even looking properly at the fruit. According to Pirqe R. El. 21 Cain brought of the remnants of his meal and some flax seed as his gift.

57 Byron, Cain and Abel, 47.

58 Pirqe $R$. El suggests that the type of offering, a leftover meal, was insulting. After discussing Cain and Abel's offerings, Pirqe R. El. warns against mixing the two offerings in terms of Deut 22:11 and Lev 19: 19's prohibition of mixing two types of material in a single garment.

59 Vermes, “Targumic Versions,” 111-12. 
some of their fat. To the rabbis in Gen. Rab. it became a question of the kind of offering that is being suggested here: a fat first born or a first born cut open with the fat exposed. Additionally, the deity was more responsive to Abel's offering than to Cain's in the four texts, with $T g$. Ps.-J., now as usual, adding to it by translating "having regard for" twice: It was pleasing before the Lord, and he turned a friendly face.

\section{$4 \quad$ Cain's Reaction}

Neither Gen. Rab. nor the Targums heap scorn on Cain as some of the other interpretive traditions did. ${ }^{60}$ The Targums do not appear to exploit Cain's reaction to the rejection of his sacrifice by the deity. Genesis 4:5 is quite straightforward here: Cain became angry and depressed. I think that is a basic human reaction to disappointment, reflected in various ways in the Targums: Tg. Onq. uses the ithpaal (אתככישו) as a more expressive way to depict Cain's dejection; Tg. Ps.-J. literally says Cain's face fell as if all splendour has been removed from it, and $T g$. Neof. focuses on the burden of grief that is heavily laid on Cain.

The texts do not mention how the two brothers came to the knowledge of the deity's reaction to the offerings. Of interest is Cain's reaction to the realisation that his sacrifice was not accepted. Abel is not attributed any reaction in this regard, only Cain is. André Wénin reads into the description here a particular jealousy on Cain's part. ${ }^{61}$ Angela Kim draws a link between Cain's name, the rivalry between the twin brothers and Cain's reaction to the deity's rejection of his sacrifice. ${ }^{62}$ Cain's name, meaning to acquire possession (קין) as well as envy (קנא), the sibling rivalry and his anger "generate a stream of ancient interpretations which fuse envy and wickedness with the very nature of Cain."63

A link is drawn from Cain's childhood to his adulthood, as if in a singular unified personality. Thus, the root of Cain's envy and wickedness is looked for in his name and the deity's capriciousness is ignored. Abel's murder "becomes a consequence of the conflict between good and evil" and not “Cain's anger over YHWH’s rejection of his sacrifice.”64 Genesis Rabbah 22.6

60 For example, Ephrem's Commentary on Genesis. Pirqe R. El. 21 describes Cain's emotion as one of hatred against his brother not only because of the rejection of his offering, but also because of Abel's beautiful twin sister he so desired. Hate and women become the two causes for the fratricide.

61 Wénin, “Adam et Eve,” 14 speaks of a jealousy that flares up with Cain's rejection by the deity, but it is in fact a sentiment with deeper roots. The deity's choice in favour of Abel only exacerbated the situation.

62 Kim, "Cain and Abel," 77-8.

63 Kim, "Cain and Abel," 77.

64 Kim, “Cain and Abel,” 80. 
Snyman, “Cain and Vulnerability,” OTE 29/3 (2016): 601-632 615

refers to Cain's face becoming like a firebrand, or blackened from burning. Subsequently most translations translate the word with anger (Cain became very angry).

The Hebrew word חרה from ויחר (חרה ) means to ignite or flare up, but the subject here is not mentioned. It is usually linked up with anger. ${ }^{65}$ Mayer Gruber questions this practice and he associates Cain's fallen face, or fallen countenance with sadness and depression. ${ }^{66}$ The word חרה is usually associated with the nose (אף), literally meaning "the nose burns," indicating the reddening of the nose and cheeks of an angry person's increased blood circulation. ${ }^{67}$ Deuteronomy 19:6 refers to the hearth that is inflamed, indicating a rise in bodily temperature. Gruber found similar expressions in Akkadian where they are juxtaposed with idioms denoting sadness and depression. ${ }^{68}$ He then makes the following statement:

The transference to descriptions of sadness, grief, or depression of expressions denoting burning, whose biological basis is the increased bodily activity characteristic of anger, and not the slowing down of bodily activity characteristic of depression, suggest an intuitive grasp of a thesis advanced in this century [sic] by Karl Abraham and Sigmund Freud, namely, that depression is anger turned inward upon the self. ${ }^{69}$

In Gen 4:5 חרה is used in conjunction with the preposition ל and the pronominal suffix third person masculine. Read with Cain's fallen countenance, it denotes depression according to Gruber, turning the story into an example of depression and not the dangerous effects of anger. And instead of laying blame on Cain for his anger, Cain's reaction appears to be quite normal in psychological terms. ${ }^{70}$

\section{The Deity's Question}

If Cain's reaction is a humane reaction based on disappointment, then the deity's rhetorical question becomes one not so much castigating Cain for his anger as one intended to lift him out of his depression. ${ }^{71}$ However, in the read-

65 Georg Sauer, “חרה,” THAT 1:633-635.

66 Mayer I. Gruber, "The Tragedy of Cain and Abel: A Case of Depression,” JQR 69 (1978): 90.

67 Gruber, “Tragedy,” 91.

68 Gruber, “Tragedy,” 92.

69 Gruber, “Tragedy,” 92.

70 Gruber, “Tragedy,” 94 argues that Cain experienced the loss of the love object à la Freud and with it a loss of self-esteem, resulting in depression.

71 Gruber, "Tragedy," 95 reads v. 7 in terms of a contrast with fallen countenance as smiling or happy, that is, the face being lifted up: "This interpretation suggests that the verb têtî̉ may also be an ellipsis. If $s^{e}$ 'êt pānîm, 'smiling,' is the antonym of 'your 
ing traditions of Gen. Rab. and the Targums, there is an accusatory tone with Gen. Rab. seeing the deity's speech as a lesson on sin. ${ }^{72}$ The MT in Gen 4:6-7 is not clear, but Jewish interpretive tradition simply adds more information.

Genesis Rabbah 22.6 provides a treatise on blessing and curse. Johanna Erzberger's detailed study shows that some textual traditions representing Gen. $R a b$. here bring into play two texts from Leviticus (chs. 9 and 22) with regard to the blessing and the curse pronounced in the text: "If you do well, will you not receive a blessing; and if you do not well, a curse?"73 According to Erzberger, the allusion to the priestly functions in these texts makes Cain not a carrier but a mediator of divine blessing. With a reference to Ps 32, the text also alludes to the alternative to blessing and curse, namely forgiveness and the increase of guilt.

The discussion of forgiveness and guilt stacks the odds against Cain, urging the reader to conclude the moment Cain commits fratricide that he failed to master the evil inclination. The hold of evil on him would be like the rope of a ship; a traveller that usurps the master of the house; or a dog waiting for the right moment to steal bread from the baker. Cain would in the end not be strong enough to fend off sin that is crouching at the door, or acting like a bully siphoning awards from those weaker than himself. All in all, Cain is regarded as weak with sin as strong as a man. Sin is personified as a thief hiding at a crossing and blackmailing each one entering the crossing. In another image it is regarded as being in the centre of a street preying on "a person rolling his eyes, smoothing his hair [in self-satisfaction], and lifting his heel [in pride].” If the evil inclination is not kept in check in childhood, one will not be able to rein it in in adulthood. It will in the end rule one like the slave who becomes a master. The Torah is the only antidote against the evil inclination, and Gen. Rab. 22.6 cites here Gen 4:7: "You shall rule over it." But Cain did not have the Torah yet. He could not be taught.

The Targums introduce an eschatological element, namely the Day of Judgment, a common theme in apocalyptic and rabbinical writings. The Tg. Onq. paraphrases the difficult Masoretic text and introduces the Day of Judgment in the deity's proposition:

Surely if you will improve your deeds, you will be forgiven; but if you will not improve your deeds, (your) sin will be kept for the Day

face has fallen,' têtîh ought to be the antonym of hārạ̄h lāk, 'you are depressed,' and should mean 'you are happy.'”

72 Byron, Cain and Abel, 58 argues that "[i]t is only in the Cain and Abel story that sin makes its debut and only in relation to Cain. Cain, therefore, has the distinction of being the first human condemned for an act that is defined as sin.”

73 Erzberger, Kain, 76. 
of Judgment when punishment will be exacted of you, if you will not repent; but if you will repent, you will be forgiven. ${ }^{74}$

All three Targums emphasise the power one has over sin. In Tg. Onq., repentance signifies power over sin. In $T g$. Ps. $-J$. the argument becomes more intricate. The text attributes guilt to Cain and provides a suggestion for the rejection of Cain's sacrifice: Cain did not perform his deeds well. Cain is admonished to exert power over the evil inclination, namely to be innocent or to sin. Tg. Ps. $-J$. and Tg. Neof. speak of the evil inclination, a typical rabbinical expression that is also found in Gen. Rab. 22. In both Cain is said to be able to control the evil inclination, a control that is not that simple or clear in Gen. Rab. Gen. Rab. 22.6's proclamation in the words of Ps 32:1, "Happy is the man that rules over his transgressions and not let the transgressions rule over him," receives an ironic twist when Cain moves away from the face of the deity and establishes his own community where he lives successfully. It is as if Cain can only rule over his transgressions away from his clan and the deity.

\section{$6 \quad$ Prelude to the Murder: The Conversation in the Field}

Genesis 4:8 suggests that Cain and Abel had a conversation in the field, but the reader remains none the wiser about the contents of the conversation. It could be that the text is silent because the two brothers had nothing to say to each other, only unbelievable violence. ${ }^{75}$ After all, violence is the logical outcome when people have nothing to say to another any longer.

The MT does not account for any conversation, and it is mainly the Targums (with the exception of $\mathrm{Tg}$. Onq.) that elaborates on the assumed conversation. Tg. Onq. follows the MT here and does not provide the conversation with any contents. Without a conversation the murder of Abel can be linked to Cain's discomfort, unease, or depression and rebellion with regard to the non-

74 The phrase "sin is crouching at the door" was thought to be too abstract and vague for popular consumption and would have led to undesirable speculations and superstitions. The translation by Aberbach and Grossfeld provide a rather intricate explanation for the use of the day of judgment: The word for entrance or door (פתח) is syntactically related to gate (שער) which is used to denote courts (בית דין or בית דינא or (פתח). The Targum Onkelos uses פתח for דין. The words crouching at the door implies an intransitive state and this translates into "your sin will be kept for the day of judgment." This addition required further explanation, so that the Targum added "when punishment will be exacted upon you" with a proviso of repentance. Cf. Moses Aberbach and Bernard Grossfeld, Targum Onkelos to Genesis: A Critical Ananlysis Together with an English Translation of the Text (Based on Sperber's Edition), Center for Judaic Studies, University of Denver (New York: Ktav Publishing House, 1982), 41.

75 Douglas B. Sagal, “'Imaginative Insight': Midrash and African-American Preaching,” Judaism 50 (2001): 7. 
reception of his sacrifice. Once a conversation is created, the conversation gets linked to the eventual murder.

Gen. Rab. 22.7 fills the conversation with three topics: the issue of land, the location of the temple and a woman. The subsequent result of the rhetoric, according to Erzberger, is that the two brothers are juxtaposed without valuing the dynamics that led to the choice for Abel's sacrifice yet laying the responsibility on Cain. ${ }^{76}$ The issue here is a dispute between brothers with the deity's role only figuring in the background. Ultimately, the impression left is that it was not his rejection of the sacrifice that gave occasion to the murder, but the subsequent quarrel. With the issue of land, it is not clear what belongs to whom. ${ }^{77}$ The second issue, the location of the Temple, or Zion, turns the quarrel into a battle for the central location of worship in Israel, and the subsequent result is that the temple (which is signified by the reference to field in Gen. $R a b .22 .7$ ) is built on the place where the first murder was committed (that is, the field in which Cain killed Abel). ${ }^{78}$ The third issue refers to the twin sister borne with Abel. Cain wanted her because he was the elder son and Abel wanted her because she was borne with him.

The Palestinian Targums (Tg. Ps.-J., Tg, Neof., Frg. Tg. and the Cairo Geniza Fragments) construct a conversation in which Cain takes at least two heterodox position over-against Abel's orthodox and accepted position. ${ }^{79}$ Bassler alerts one to the fact that the words from Cain "reveal[s] that at least two different yet recognizable heretical positions are being pilloried in the different targumic recensions." 80

In $T g$. Ps.-J. Cain argues that the world proceeded from love or mercy, but he denies justice in the government of the world. Cain subscribes only to a link between the deity and mercy or love, but not to justice. In $\mathrm{Tg}$. Neof. he

76 Erzberger, Kain, 80.

77 Erzberger, Kain, 80: "Die Darstellung der Auseinandersetzung impliziert noch keine zwischen den Brüdern differenzierende Wertung."

78 Erzberger, Kain, 81 refers to a textual tradition of Gen. Rab. that links the field with Deut 22:23-27, alluding to the cry for help but no one could hear. Hence Abel's blood is crying from the ground in the field: "Wie die Frau schreit (צעק), schreit (צעק) nach Gen 4,10 das Blut des getöteten Abel.“

79 Jouette M. Bassler, "Cain and Abel in the Palestinian Targums: A Brief Note on an Old Controversy,” JSJ 17 (1986): 58. Bassler refers to the problem of the presentation of Cain's part in the conversation which seems to differ in the Targums and reflects a different polemic every time and thus with it the nature of the contemporary issue reflected in the conversation. She reproaches Martin McNamara, The New Testament and the Palestinian Targum to the Pentateuch, vol. 27 (Rome: Pontifical Biblical Institute, 1966), Grelot, "Les Targums," and Vermes “Targumic Versions,”) for either brushing off the differences or for simply ignoring them.

80 Bassler, "Cain and Abel," 60. 
denies the existence of love as well as justice. He does not see any link between the deity and mercy and justice. In $T g$. Ps.-J. love is negative and indicates capriciousness, but in $\mathrm{Tg}$. Neof. love is mercy. Cain disbelieves any divine justice in the present world as well as the world to come: the deity's acceptance of Abel's offering is based on favouritism, a stance contradicted by Abel who argues that his actions were better and in fact more punctual. ${ }^{81}$ In the Geniza fragments he only links the deity to mercy or love. If mercy dictates the deity's behaviour, it means that the deity's justice is wanting. ${ }^{82}$ Abel represents the orthodox position: "Justice and mercy are complementary attributes of the one God, who indeed shows mercy even as He judges, and justice even as He is merciful." 83 The deity takes into account "the fruit of good deeds" and that was the basis for the acceptance of Abel's offering. ${ }^{84}$ Cain challenges this unity of the deity and he embodies those who see two independent manifestations of the deity on the basis of the biblical evidence in the two names of the deity, the two forms of the deity and these two attributes. ${ }^{85}$

In this interchange Cain becomes the first heretic and sinner whereas Abel is depicted as the just teacher and martyr, a characterisation originating from the exigence in the first century CE which Vermes relates to the controversy between the Sadducees and Pharisees about the future world. ${ }^{86}$ Abel voices the rabbinic teaching, ${ }^{87}$ upholding love as well as justice.

Love and justice were believed to be manifest in the biblical texts, with Cain as one example in receiving reprieve for a time, yet according to justice, forfeiting his life. ${ }^{88}$ But the Masoretic text does not distinguish between the

81 Vermes, “Targumic Versions,” 115. See also Chilton, “Comparative Study,” 557.

82 Chilton, "Comparative Study,” 557.

83 Bassler, "Cain and Abel," 61.

84 Chilton, “Comparative Study,” 557.

85 Bassler "Cain and Abel," 62 argues that the Geniza fragments reflect a heresy of two powers. In $T g$. Neof. a new controversy crops up, with Cain no longer seeing only one attribute of the deity, but outright denying both. Bassler sees this as Cain rejecting a key aspect of Judaism: "Thus the contemporary debate reflected here is not with a two-powers heresy, but with an eschatological heresy that denied divine judgment of human affairs and resurrection existence." And the candidates for this heresy are thought to be either the Sadducees or Epicurians. See also Chilton, "Comparative Study," 558, who points to the absence of a clear denial by Abel with regard to favouritism on the side of the deity as well as the lack of insistence on timeous behaviour.

86 Vermes, “Targumic Versions,” 116.

87 Chilton, “Comparative Study,” 558, argues that Abel's response is “perfectly symmetrical to Cain's attack, and suggests that these specific affirmations are key tenets in the mind of the meturgeman."

88 Vermes, "Targumic Versions,” 125. Bassler, "Cain and Abel,” 60 argues Vermes does not adequately "delineate the actual contemporary issue reflected in the short 
moral dispositions of the two brothers; ${ }^{89}$ one only knows that they are viewed differently by the deity. Jewish exegesis, however, draws the conclusion that Abel is pious and just and Cain evil and impious. Says Roger Le Déaut:

Ils deviennent comme les «types » des deux catégories où la pensée juive aimera ranger les hommes: les צשעים et líxaol et Tounpoí). ${ }^{90}$

Le Déaut indicates the important function this dispute has in the Targums: Cain only kills Abel at the end of the dispute, after providing the reader with a confession of faith (or non-faith) "en rapport étroit avec le sacrifice offert à Dieu par l'un et l'autre, mais diversement agréé."91 The dispute turns the two brothers into

les types littéraires de deux catégories humaines: celle des pêcheurs, dont les œuvres sont mauvaises et qui vont jusqu'à nier les fondements de la foi; celle des justes, dont les œuvres sont bonnes et qui professent la vraie foi. ${ }^{92}$

Cain in the Targums becomes the zenith of impiety and Abel the true martyr. Both expressed a confession of faith, which, when tied directly to their respective offerings, explain the respective rejection and acceptance of the offerings. $^{93}$

\section{$7 \quad$ The Murder}

The three Targums under discussion all proclaim Cain rose up against his brother and killed him. Only $T g$. Ps.-J. provides the reader with a weapon with which Cain is killed: a stone. ${ }^{94}$ Gen. Rab. 22.8 embroiders on four aspects in

recension (PTG), even though he recognized the distinguishing features of this recension.”

89 Roger Le Déaut, “Traditions Targumiques dans le Corpus Paulinien?” Sem 42 (1961): 31.

90 Le Déaut, “Traditions Targumiques?” 31. He regards this kind of depiction as typical to the ancients, such as Josephus and the New Testament authors.

91 Le Déaut, “Traditions Targumiques?” 32.

92 Grelot, "Les Targums," 72. Grelot's article aims to look at the relationship between the different targumic texts and variants in Gen 4, so that his theological observations is limited and generalised. See Bassler, "Cain and Abel," 59.

93 Le Déaut, “Traditions Targumiques?” 33.

94 Pirqe R. El. too follows this tradition in stating that Cain took a stone and embedded it in Abel's forehead and slew him. However, in most depictions of Cain killing Abel, one sees him with the jawbone of a donkey. Alphons A. Barb, "Cain's MurderWeapon and Samson's Jawbone of an Ass," JWCI 35 (1972): 386-389, argues that the word utilised here (הרג) and connected with Is 27:1 (חרב a sickle of sorts) indicates slaughtering by cutting throats. He thinks of an instrument with a cutting edge. Cain, being a tiller of the soil, would have owned such an instrument for harvesting pur- 
the story in this instance: Abel's physical strength, the weapon, the place of the murder and a rhetorical question posed by Abel before the fatal blow.

Firstly, the fact that Cain is said to have risen up against Abel, is interpreted as that Abel appeared to have been stronger and overpowered Cain, just to release him again, at which moment Cain took advantage of Abel's compassion and struck him. Gen. Rab. appears to describe a physical fight. Secondly, Cain's deviousness becomes all the more apparent when his fatal blow is delivered just after Abel's sympathetic question to Cain on the realisation of what Cain is about to do, namely what is he going to say to their father. ${ }^{95}$ All in vain, though, and Gen. Rab. concludes with a wisdom saying said to have originated here and it is about not doing good to evil so that evil do not reach you. Thirdly, Gen. Rab. deliberates about the murder weapon, a stick or a stone. The Midrash brings Gen 4:23 into play here with the two kinds of wounds suggested in the verse: a bruise originating from a stick, or a wound originating from a stone. ${ }^{96}$ Fourthly, the place of the murder seems important to Gen. Rab., as it is suggested that Cain thought about the place where his father killed the bulls. Psalm 69:32 is cited and it is clear here that Cain thought of the killing of his brother as some kind of sacrifice. With Erzberger one should not let the irony escape here! ${ }^{97}$ It is as if Cain is thinking that Abel's sacrifice is more worth than a sacrifice of a bull or an ox. This place then becomes the place where Cain slaughters Abel, "by the throat and its organs."98 If Abel is slaughtered in this way, then the weapon becomes something like the jawbone of a donkey.

The Masoretic text is silent about what happened to Abel's body. Two manuscripts of Gen. Rab. 22.8 relate a funeral $^{99}$ whereas the Geniza Fragments turns Cain into an ignorant in the heat of the physical struggle: he had to observe two birds in combat to "learn" what he can do with Abel:

poses. Ancient depictions of such instruments (he found an Egyptian hieroglyph) represent a sickle-like instrument with sharp teeth, representing in all likelihood the form of the jawbone of a donkey. It is merely a form, as archaeological finds from Neolithic times have revealed wooden instruments with serrated blades. He argues that the shape and construction of these instruments indicate that the donkey jawbone could have been the original instrument.

95 See Erzberger, Kain, 82.

96 Erzberger, Kain, 82 says the mentioning of the two kinds of wounding suggests an aggravation.

97 Erzberger, Kain, 82.

98 As translated by Freedman, “Introduction.” Erzberger, Kain, 83 translates differently but acknowledge the difficulty in the translation: "am Ort des Nackens, am Ort der Zeichen." She suggests that the place of the sign refers to the mark Cain will receive.

99 Erzberger, Kain, 83. 
Abel found no place to go out to and he (Cain) did not know with what he would strike him. He turned here and there until he saw two birds fighting and one arose against the other and struck it in the mouth and the blood spurted out until it died. Cain learned from it and did the same to Abel his brother.

But his learning curve did not stop there. Once he killed Abel, he did not know what to do with the body. Again he observed birds:

He raised his eyes and saw the bird that had killed its fellow putting its mouth to the ground, digging a hole and burying its dead neighbor, and putting earth over it. At that moment Cain did the same with Abel, so that his father might not find him.

Erzberger reminds one of the learning and teaching motif in the Gen. $R a b$. interpretation of Gen 4: in v. 1 Adam is the teacher in begetting life, Cain is the learner. Here Cain learns from the birds, but for the rest after him, he became the teacher of death and funeral. ${ }^{100}$

\section{The Blood of Abel}

When the deity starts his inquiry about the whereabouts of Abel, Gen. Rab. 22.9 provides three examples of reactions of being caught red-handed, illustrating the futility if Cain would proclaim innocence. His physical condition is that of hands dripping with blood and Abel's blood crying from the ground. Gen. Rab. first describes the situation of a police guard finding two men in the road, the one lying on the ground, dead and the other standing over him. When the police guard asks who killed the man, the one standing over the dead body claims the same question upon which the police retorts that the one standing there answered nothing. In the second example a man enters a garden without authorisation to pick mulberries. When challenged by the owner, he denies everything despite his hands dripping with mulberry juice. And in the third example, a man enters a pasture and steals a goat, throwing it over his back. When challenged by the owner, he denies everything yet the goat keeps bleating behind his back. Cain has no excuse. And all these haggadic materials lead to the blood of Abel crying from the ground.

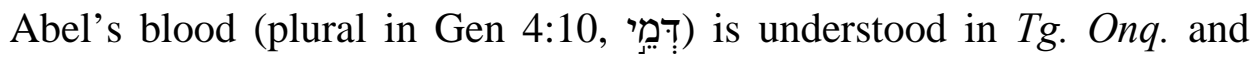
$T g$. Neof. also to be plural. $T g$. Onq. reads it as the voice of the blood of the descendants that would have been born if Abel was alive to procreate. Tg. Neof. reads it as the blood of the righteous multitudes that were to arise from Abel.

100 Erzberger, Kain, 83: “Ist Inhalt des Lehrens und Lernens nach der Auslegung zu V 1 Lebensweitergabe, sind es hier die (gewaltsame) Tötung und das Begräbnis. In der Auslegung zu V 1 tritt Adam als Lehrer auf. Als solcher fungiert er auch in der Auslegung zu V 8. Stärker gemacht wird jedoch die Schülerrolle Kains. Implizit ist die Rolle Kains als Lehrer für alle, die nach ihm kommen.” 
Cain suddenly came to be seen to have committed genocide. $T g$. PS.-J. does not read it in the plural, but focuses on the soil that will be cursed and not yield any fruit to Cain because of the blood the clay had to swallow. Gen. Rab. also follows the interpretation by $T g$. Onq. and Tg. Neof., contrasting it with Naboth and Jojadah's blood being spilt in the plural and not singular. Abel's death is not only about loss of life, but also the destruction of possible progeny. ${ }^{101}$ This seems a serious issue, because after explaining the plural of blood, Gen. Rab. expresses a retort, questioning the deity's lack of intervention. It does not do it lightly: "R. Simeon b. Yodai said: It is difficult to say this thing, and the mouth cannot utter it plainly." Gen. Rab. then refers to two athletes wrestling before the king in a battle to death. The king refuses to intervene and one has to kill the other. The victim then cries out: "Let my cause be pleaded before the king!" The victim in fact blames the king for not intervening. Abel's death is laid before the deity. Moreover, Abel seems to be neither here nor there anymore: his blood has spattered over the trees and stones with his soul unable to ascend or descend. It is not only Abel's life that was taken away, but also his afterlife. And the spattering of the blood indicates the brutality with which the murder took place. The murder was vicious with far-reaching consequences that will shape generations to come.

\section{$9 \quad$ Cain Cursed}

In contrast to the punishment given to Adam where the earth will be cursed for him, Cain is cursed with the earth refusing to yield anything for him (Gen 4: 11-12). Byron says the earth, rather being cursed, plays an active role in the curse placed on Cain. ${ }^{102}$ In fact, it is as if the entire creation conspires against Cain. Thus Gen. Rab. 22.10 refers to the cattle, the beasts, and the birds demanding justice for Abel. The link between the blood-soaked soil and Cain's curse is that the blood of Abel causes the earth to no longer yield any fruit to Cain. Tg. Onq. and Tg. Neof. link the curse with the earth that is filled with Abel's blood. It is noteworthy that Tg. Onq. makes Cain more cursed than the earth whereas Tg. Ps.-J. links the act of murder to Cain's curse.

In Gen. Rab., with two brief references to Judges and Numbers, the deity's role is yet again under scrutiny: he did not intervene with the death of Abel, just as he failed to intervene with the promise Jephthah made. The reference to the Jephthah story (Judg 11) as well as the story of Dotam and Abiram (Num 16) underline the serious consequences of one's actions. ${ }^{103}$ With the Dotam and Abiram story a parallel is drawn with the Cain and Abel story. Just as Cain's sacrifice is not accepted, the sacrifice supposedly given by Dotam and Abiram is also not accepted (albeit on instigation by Moses). Dotam and

\footnotetext{
101 Erzberger, Kain, 86.

102 Byron, Cain and Abel, 97.

103 Erzberger, Kain, 87.
} 
Abiram are then first separated from the rest of Israel and subsequently killed. Cain is cursed and ultimately driven away. He would have been killed were it not for the mark he receives later on.

Cain's livelihood is under attack: the earth will not yield according to the measure he will be putting into it, very similar to the situation of the transgressions of the covenant described in Deut 28. The point of comparison is that in both instances the soil refuses to yield its power and the result is the loss of land, for Israel in Deuteronomy and for Cain in Genesis. ${ }^{104}$ Cain will be able to survive though, but he will have to toil for it. It will not be provided without any sweat.

\section{Cain's Reply}

Given the severe consequences suggested in Gen. Rab. 22:10, Cain's acknowledgement of his own defencelessness in Gen 4:11 is understandable. The question is whether he proclaims fragility or vulnerability. The MT reports Cain saying: "My punishment is greater than I can bear." Gen. Rab. 22.11 presents the reader with a vulnerable and a fragile Cain. Cain's fragility is revealed in the first argument that is put into his mouth; he asks the deity the following: "You bear the heavenly and the earthly, yet you cannot bear my transgression?" Byron sees it as a "complaining accusation that seeks forgiveness."105 God carries the entire world, the divine as well as the human reality, and the question is whether he cannot carry Cain's guilt. Erzberger sees this as a rhetorical question, ${ }^{106}$ but it is not a neutral question: is Cain not critiquing the deity here, as he is critiqued in Gen. Rab. 22.9 for his failure to act in the battle between Cain and Abel? Targum Neofiti and Tg. Ps.-J. portray Cain's fragility in that he confesses but protests the deity's refusal to forgive his crime:

Tg.Neof.: my debts are too numerous to bear; before you, however, there is power to remit and pardon.

Tg.Ps.-J.: My rebellion is much too great to bear, but you are able to forgive it.

In all three examples, Cain prescribes to the deity a course of action. Should Cain not rather be keeping quiet? The Rabbis did not think so. ${ }^{107}$

Targum Onqelos portrays Cain in his vulnerability by having him professing his guilt: "My guilt is too great to be forgiven." And then Cain is

104 Erzberger, Kain, 88.

105 Byron, Cain and Abel, 104.

106 Erzberger, Kain, 88.

107 Byron, Cain and Abel, 105 argues that Cain's supplication in Tg. Neof. and Tg. $P s .-J$. is a prayer for forgiveness based on the knowledge of the deity's ability to forgive. 
Snyman, “Cain and Vulnerability,” OTE 29/3 (2016): 601-632 625

silent. ${ }^{108}$ In Gen. Rab. 22.11 the rabbis let Cain speak again, this time putting forward another argument, which portrays his vulnerability and not fragility. In this argument Cain acknowledges his sin as larger than his father's: murder is a major crime making the sin all the more grave. Subsequently his punishment will be harsher than that of Adam. In Gen. Rab. 22.11 the comparison with Adam underlines the critical significance of the murder and its consequences. In fact, Cain seems to undertake the punishment on himself in stating that he will hide himself and become a wanderer and fugitive. Like his parents who were removed from the physical presence of the deity, Cain removes himself physically from the presence of the deity as well as his parents or clan.

\section{Punishment}

What is this punishment? In Gen 4:14 Cain is said to be driven from the surface of the earth, hiding from the deity and becoming a restless wanderer. Targum Onqelos says Cain is expelled from the face of the soil and it is impossible for Cain to hide from the deity. The imperative of hiding in the MT becomes an impossibility. Genesis Rabbah 22.11 takes the comparison with Adam further: Adam was driven out first and now the deity drives out his son, and Cain asks himself whether it is at all possible to hide from God. The Targums do not think one can hide from the deity, as it will put a limitation on him.

In the explanation of v. 15 Gen. Rab. 22.12 embroiders on the seriousness and consequences of Cain's murderous action: the entire creation wanted revenge or justice for Abel, ${ }^{109}$ but the deity asks clemency for Cain because he had no one to learn from. The deity defends Cain in front of the creation. Cain himself now becomes a teacher, as anyone after him doing the same, will be slain. The question is, though, whether an admission on Cain's part would indicate he learnt something. ${ }^{110}$ Cain feared that whomever he meets, will be able to slay him as he has slain Abel. Genesis Rabbah argues, since there are no other people around, Cain's fear is about the animals (cattle, beasts and birds) who may attack him.

God protects Cain in providing him with a mark in Gen 4:15. The contents or appearance of the mark is unknown. Genesis Rabbah 22.12 discusses four instances that may constitute the mark of Cain. A rabbi is said to have proclaimed the sun over Cain, only to be challenged by another, scoffing at the idea of the sun shining over Cain and rather having him developing leprosy. A third one says the sign was a dog and a fourth one claimed the mark to be a

108 Byron, Cain and Abel, 105 with reference to Vermes, "Targumic Versions," 118, argues that $\mathrm{Tg}$. Onq. emphasises Cain's guilt, showing his despair but not revealing him as repentant. The evidence supplied by both does not carry their argument.

109 Erzberger, Kain, 89 refers to the different manuscripts of Gen. Rab. in this regard. The majority of texts seek revenge whereas only two seeks justice.

110 Erzberger, Kain, 88 thinks so. 
horn. Two others picked up on the idea of Cain teaching others and a last one said that God suspended judgment until the flood. And one argued that he was made into an example to penitents. The point seems to be Cain was not immediately killed by the deity or an agent of the deity.

Targum Onqelos and Tg. Neof. do not elaborate on the mark Cain receives but explains the timing of the punishment on Cain, interpreting the period of seven generations which is ambiguously put in the MT, differently. ${ }^{111}$ To Tg. Onq. Cain will receive his punishment after seven generations whereas $T g$. Neof. says that judgment for anyone killing Cain will be suspended for seven generations.

The story ends with Cain leaving the presence of the deity to settle in the land Nod, east of Eden. Cain leaves the presence of the deity as well as of his family. The land Nod is interpreted in $T g$. Onq. as the land of exile and restlessness, whereas and $T g$. Neof. describe Cain as an exile and a wanderer. In Tg. Ps.-J. Cain is said to leave the presence of the deity to settle in the land of the wandering of his exile. It adds a note on the role of the land: whereas it yielded its produce to Cain before the murder, its produce became thorns and thistles afterwards.

Genesis Rabbah 22.13 provides two comments on Cain's leaving the deity and his clan. He first explains negatively what it would have meant that Cain went out: Cain rejected the deity's reproof-he went out like one deceiving the Lord; he went out like one who shows a cloven hoof, that is, a hypocrite-a pig showing a hoof pretending it is clean. But then, secondly, Cain is portrayed as leaving while rejoicing, recounting to Adam he repented and became reconciled with the deity. I am not sure the reader believes Cain at this point. It is only when Adam enters the picture, citing Ps 92, that the reader may accept Cain's position. A first reading of Cain's encounter with Adam, together with Adam's reaction, left me with the impression of Cain having turned the deity around his finger, making Adam realised how easy it is to manipulate the deity. But the reference to Exod 4:14 and Ps 92:1 brings into play the relationship of Moses and Aaron as well is a song of thanksgiving in Adam's mouth for salvation from the enemy. Just like Aaron was filled with joy in meeting Moses, so was Adam in his encounter with Cain who murdered his other son. The encounter between Moses and God in the burning bush became via Aaron's general knowledge about and experience of God. Says Erzberger:

In der Deutung des Midrasch werden Kain und Adam zu Empfängern und zu Vermittlern einer aus erlebter Gottesbeziehung

111 Byron, Cain and Abel, 106-113 discusses the ambiguity of the seventh generation and its interpretation in the Jewish tradition. It is not clear whether Cain received punishment in sevenfold or whether he was killed (accidentally?) in the seventh generation by Lamech after leading a long and difficult life. 
resultierenden Gotteserkentnis. Subjekt erfahrener Gottesbeziehung ist Kain. ${ }^{112}$

Ps 92 contrasts the fortunes of the evildoer and the just. Adam uses the psalm and prays it to the deity on behalf of Cain. But Adam, like Cain, is the evildoer and with the psalm he endeavours to heal the relation between himself and the deity as well as between the deity and Cain:

Indem Adam den Ps in eigener Sache und in Antizipation der Erfahrung Kains von der größeren Macht der Umkehr und der Annahme dieser Umkehr durch Gott spricht, werden beide nicht mehr unter der Feinde Gottes gezählt, von denen V 10 spricht. $^{113}$

\section{E CONCLUSION}

I have set out to answer the following question: Does the reception of the story in the three mentioned Targums as well as Genesis Rabbah allow for vulnerability or is Cain depicted as the murderer par excellence for whom no redemption is possible? The Jewish tradition as presented in Tg. Onq., Tg. Neof., Tg. Ps.-J. and Gen. Rab. is not unified in their understanding and portrayal of Cain. To some Cain remains the perpetrator par excellence with no possibility of redemption, to others, despite portraying him in extremities of corruption; ultimately he deserved to be forgiven, although it did not mean the suspension of justice. Cain still had to undergo the punishment.

Targum Pseudo-Jonathan stacks the odds against Cain from the very beginning by linking Cain to Samael, the personification of evil, as his father. The other three texts follow the MT which links Adam to Cain, although Eve's pronunciation at birth does not link Adam to him. Gen. Rab. goes further and links siblings to Cain and Abel, laying the ground work for the quarrel between them that will eventually kill Abel. It also provides later a wife for Cain. Gen. $R a b$. further prepares the ground for Cain's wrongdoing in suggesting that his vocation is problematic in that at least two others who were tillers of the soil encountered problems.

With the Masoretic text's silence on the reason why Cain's offering is not accepted, the Jewish tradition had a field day in filling that gap! It all boils down to Cain bringing a defective sacrifice: for Gen. Rab. he did not follow the regulations and for the Targums he brought it at the inappropriate time. To them 14 Nissan is indicative as the date relates to creation, the offer of Isaac and Passover. Cain was in the wrong, bringing flax or meal leftovers instead of a lamb. His failure here is indicative of his evil nature.

112 Erzberger, Kain, 92.

113 Erzberger, Kain, 93. 
Yet his reaction is treated delicately. Neither the Targums nor Gen. Rab. heap scorn on him, yet they depict his reaction differently. The context of each presentation will lead the reader to attach positive or negative value to his anger as hatred or depression and regard the deity's rhetorical question either as a castigation and reprimand or a pastoral effort to lift him out of his depression. But the Targums as well as Gen. Rab. have an accusatory tone which slants Cain's anger towards evil and not depression. They all admonish him to rule over sin, or the evil inclination-it is as if the texts prepare the reader for what follows: Cain will succumb to the evil inclination.

The MT with $T g$. Onq. leave a gap when Cain and Abel go into the field. Gen. Rab., Tg. Neof. and Tg. Ps.-J. (with the Frag. Tg. and the Geniza Fragments) fill this gap with an assumed conversation. Gen. Rab. suggests three topics whereas the other Targums provide a theological discussion in which Cain plays the heretic. In all the conversations Cain does not toe the line and uses violence to get what he wants. Cain's lack of proper faith is seen as the cause for the murder-he is the ultimate sinner from whom one can only expect a murder.

The Targums and Gen. Rab. also fill in the detail of the murder not mentioned in the MT. Abel is the one with reason and physical strength and Cain overpowers him deviously, killing him brutally. Of interest is the suggestion that Cain is not thought of being capable to do it on his own. He needed an example, for he is a learner. In this he is distanced somewhat from the murder in that he simply did what he saw happen in the animal kingdom.

However, Cain has no excuse. Gen. Rab. portrays him as if caught redhanded whereas the Targums zoom in on the causal effect the killing of Abel had: Abel will be without descendants. Cain is portrayed as having committed genocide and the entire creation demands justice. Moreover, with the earth having absorbed Abel's blood, according to the Targums, Cain will from now on be unable to practice his profession: tilling the soil. Cain's curse is linked to the earth in the Targums: Tg. Neof. links it to the earth that drank Abel's blood, $T g$. Onq. argues that Cain is more cursed than the earth and Tg. Ps. $J$. is the only one that draws a causal link between the murder and the curse.

Cain's final response testifies either to him being fragile or vulnerable. In the MT his initial reaction is one of fragility, that is, an irritability of being caught red-handed. Once he is cursed, the question of vulnerability comes forward: does he respond in the light of any recognition of what he did? In other words, does he move from ignorance and innocence to knowledge and vulnerability? In Gen. Rab. he appears first to continue with his fragility in asking whether the deity should not be able to carry his burden. He is, after all, the deity. Is he not protesting the deity's refusal to forgive his crime? This seems to be the case. But then Gen. Rab. proceeds further in portraying Cain as 
acknowledging his sin as larger than his father's. The implication is that his punishment will also be more severe. In $T g$. Onq. Cain simply states his sin is too big to forgive and then keeps quiet.

Cain's punishment is that he is driven out, away from the presence of the deity and becoming a fugitive and a wanderer. The Targums stress that he will be unable to hide from the deity. Genesis Rabbah, although emphasising the severity of the crime by referring to the entire creation wanting justice or revenge, puts up a defence for Cain because he had no one to learn from. God protects him with a mark, which is discussed in fair detail in Gen. Rab. The Targums refer to the mark in passing, focussing instead on the duration of Cain's life before punishment will be exacted on him.

Of significance is where Cain departs to. In all three Targums the land Nod is significant in that Cain is presented as an exile, someone without a land, restless for ever. Genesis Rabbah provides two ends for the story: one in which Cain remains without regret, a hypocrite, and another in which he recounts to Adam how he received a reprieve. I am not convinced Gen. Rab.'s depiction is showing vulnerability, but rather fragility, as Cain's narration leaves the impression of manipulation of the deity's conscience. But then, I may still be influenced by the Christian tradition's utmost rejection of Cain as can be seen in 1 John 3:10-12.

\section{BIBLIOGRAPHY}

Aberbach, Moses and Bernard Grossfeld. Targum Onkelos to Genesis: A Critical Analysis Together with an English Translation of the Text (Based on Sperber's Edition). Center for Judaic Studies, University of Denver. New York: Ktav Publishing House, 1982.

Areff, Ahmed. "Listen: Whites Took Nothing from No One - Pastor Andre Olivier." News24.com, 28 June 2916. http://www.news24.com /SouthAfrica/News/listenwhites-took-nothing-from-no-one-pastor-andre-olivier-20160628.

Bacher, Wilhelm and Jacob Z. Lauterbach. "Peshat.” The Jewish Encyclopedia. New York: Funk \& Wagnalls, 1906. http://www.jewishencyclopedia.com/articles/12060-peshat.

Barb, Alphons A. “Cain’s Murder-Weapon and Samson's Jawbone of an Ass.” Journal of the Warburg and Courtauld Institutes 35 (1972): 386-89.

Bassler, Jouette M. "Cain and Abel in the Palestinian Targums.” Journal for the Study of Judaism in the Persian, Hellenistic, and Roman Period 17/1 (1986): 56-64.

Brown, Francis, Samuel R. Driver, and Charles A. Briggs. A Hebrew and English Lexicon of the Old Testament. Oxford: Clarendon, 1907.

Byron, John. Cain and Abel in Text and Tradition: Jewish and Christian Interpretations of the First Sibling Rivalry. Themes in Biblical Narrative Jewish and Christian Traditions 14. Leiden: Brill, 2011.

Chilton, Bruce. “A Comparative Study of Synoptic Development: The Dispute between Cain and Abel in the Palestinian Targums and the Beelzebul 
630 Snyman, “Cain and Vulnerability,” OTE 29/3 (2016): 601-632

Controversy in the Gospels.” Journal of Biblical Literature 101/4 (1982): 55362.

Deist, Ferdinand. Witnesses to the Old Testament. The Literature of the Old Testament 5. Pretoria: NG Kerkboekhandel, 1988.

Diangelo, Robin. What Does It Mean to Be White? Developing White Racial Literacy. Counterpoints: Studies in Postmodern Theory of Education 398. New York: Peter Lang, 2012.

Eco, Umberto. Inventing the Enemy and Other Occasional Writings. Translated by Richard Dixon. London: Harvill Secker, 2012.

Erzberger, Johanna. Kain, Abel Und Israel: Die Rezeption von Gen 4, 1-16 in Rabbinischen Midraschim. Beiträge Zur Wissenschaft Vom Alten Und Neuen Testament 12. Stuttgart: Kohlhammer, 2011.

Freedman, Harry. "Introduction.” Pages 27-29 in Midrash Rabbah Genesis. Translated into English with Notes, Glossary and Indices with Foreword by Rabbi. Dr. I. Epstein. Volume 1. Edited by Harry Freedman and Maurice Simon. London: Soncino Press, 1961.

Gilson, Erinn. "Vulnerability, Ignorance, and Oppression.” Hypatia: A Journal of Feminist Philosophy 26/2 (2011): 308-32, doi: 10.1111/j.15272001.2010.01158.x.

Ginzberg, Louis. Bible Times and Characters from the Creation to Jacob. Vol. 1 of The Legends of the Jews. Translated by Henrietta Szold. Philadelphia: The Jewish Publication Society of America, 1954. http://philologos .org/ eblotj/vol1/three.htm\#1.

Gregg, Robert C. "Cain and Abel/Qabil and Habil.” Pages 1-113 in Shared Stories, Rival Tellings: Early Encounters of Jews, Christians, and Muslims. Oxford: Oxford University Press, 2015.

Grelot, Pierre. "Les Targums Du Pentateuque: Etude Comparative d’après Genèse IV, 3-16.” Semitica 9 (1959): 59-88.

Grossfeld, Bernard. The Targum Onkelos to Genesis. Translated, with a Critical Introduction, Aparatus, and Notes. Volume 6. The Aramaic Bible. Edinburgh: T \& T Clark, 1988.

Gruber, Mayer I. "The Tragedy of Cain and Abel: A Case of Depression.” The Jewish Quarterly Review 69/ 2 (1978): 89-97.

Heinemann, Joseph. "The Proem in Aggadic Midrashim. A Form-Critical Study.” Pages 100-122 in Studies in Aggadah and Folk-Literature. Scripta Hierosolymitana 22. Jerusalem: Magnes Press, Hebrew University, 1971.

Jacobs, Irving. The Midrashic Process: Tradition and Interpretation in Rabbinic Judaism. Cambridge: Cambridge University Press, 1995.

Jacobs, Joseph and S. Theodore Horovits. "Midrash.” The Jewish Encyclopedia. New York: Funk \& Wagnalls, 1906. http://www .jewishencyclopedia.com/articles/10805-midrash.

Kim, Angela Y. "Cain and Abel in the Light of Envy: A Study in the History of the Interpretation of Envy in Genesis 4.1-16." Journal for the Study of the Pseudepigrapha 12/1 (2001): 65-84.

Kritzinger, Klippies (J. N. J.). "Response to Pastor Andre Olivier of Rivers Chruch, Sandton.” Ahmed Kathrada Foundation, 1 July 2016. http://www.kathradafoundation.org/tags/klippies-kritzinger. 
Snyman, “Cain and Vulnerability,” OTE 29/3 (2016): 601-632

Le Déaut, Roger. “Traditions Targumiques Dans Le Corpus Paulinien?” Semitica 42/1 (1961): 28-48.

Lewis, Jack P. “The Offering of Abel (Gen 4:4): A History of Interpretation.” Journal of the Evangelical Theological Society 37/4 (1994): 481-96.

Lier, Gudrun E. A Redaction History of the Pentateuch Targums: Genesis 1:26-27 in the Exegetical Context of Formative Judaism. Gorgias Biblical Studies 53. Picastaway: Gorhgias Press, 2014.

Maher, Michael. Targum Pseudo-Jonathan: Genesis. Translated, with Introduction and Notes. Volue 1b. The Aramaic Bible. Edinburgh: T \& T Clark, 1992.

McNamara, Martin. Targum Neofiti 1: Genesis. Translated, with Apparatus and Notes. Volume 1a. The Aramaic Bible. Edinburgh: T \& T Clark, 1992.

. The New Testament and the Palestinian Targum to the Pentateuch. Volume 27. Pontifical Biblical Institute, 1966.

Mellinkoff, Ruth. The Mark of Cain. Berkeley: University of California Press, 1981.

Sagal, Douglas B. “'Imaginative Insight’: Midrash and African-American Preaching.” Judaism 50/1 (2001): 3-16.

Jenni, Ernst, with Claus Westermann, ed. Theologisches Handwörterbuch Zum Alten Testament. 2 vols. München: Chr. Kaiser Verlag, 1978.

Shinan, Avigdor. "The Aggadah of the Palestinian Targums of the Pentateuch and Rabbinic Aggadah: Some Methodological Considerations.” Pages 203-17 in The Aramaic Bible: Targums in Their Historical Context. Edited by Derek R. G. Beattie and Martin J. McNamara. Journal for the Study of the Old Testament Supplement Series 166. Sheffield: Sheffield Academic Press, 1994.

Snyman, Gerrie F. “A Hermeneutic of Vulnerability: Edom in Malachi 1:2-5.” Paper presented at the annual meeting of the Society of Biblical Literature, Atlanta, USA, 20 November 2015.

. “A Hermeneutic of Vulnerability: Redeeming Cain?” Stellenbosch

Theological Journal 1/2 (2015): 633-665. doi:

http://dx.doi.org/10.17570/stj.2015.v1n2.a30.

. "Obadiah and a Hermeneutic of Vulnerability." Pages 45-63 in Obadiah.

Readings: A New Biblical Commentary. Edited by Bob Becking. Sheffield:

Sheffield Phoenix, 2016.

. "Responding to the Decolonial Turn: Epistemic Vulnerability."

Missionalia: Southern African Journal of Mission Studies 43/3 (2015): 266-91. doi: http://dx.doi.org/10.7832/43-3-77.

Vermes, Geza. “The Targumic Versions of Genesis 4:3-16.” Pages 92-126 in PostBiblical Jewish Studies. Studies in Judaism in Late Antiquity 8. Leiden: Brill, 1975.

Von Kellenbach, Katharina. The Mark of Cain: Guilt and Denial in the Post-War Lives of Nazi Perpetrators. Oxford: Oxford University Press, 2013.

Wekker, Gloria. White Innocence: Paradoxes of Colonialism and Race. Durham, N.C.: Duke University Press, 2016.

Wénin, André. “Adam et Eve: La Jalousie de Caïn, «semence» Du Serpent: Un Aspect Du Récit Mythique de Genèse 1-4.” Revue Des Sciences Religieuses 73/1 (1999): 3-16. 
632 Snyman, “Cain and Vulnerability,” OTE 29/3 (2016): 601-632

Wicks, Jeff. “Twitter Erupts after KZN Estate Agent Calls Black People 'Monkeys.”” Mail \& Guardian, 4 January 2016. http://mg.co.za/article /2016-01-04-twittererupts-after-kzn-estate-agent-calls-black-people-monkeys.

Würthwein, Ernst. The Text of the Old Testament: An Introduction to the Biblia Hebraica. Translated by Errol F. Rhodes. 2nd and rev. ed. Grand Rapids: Eerdmams, 1995.

Prof. Gerrie Snyman, Department of Biblical and Ancient Studies, University of South Africa, P.O. Box 392, UNISA, 0003, South Africa. Email: snymagf@unisa.ac.za 